\title{
ВЕЩЕСТВЕННЫЙ СОСТАВ ТОРФОВ ТИМИРЯЗЕВСКОГО БОЛОТА (ТОМСК, ЗАПАДНАЯ СИБИРЬ)
}

\author{
Савичев Олег Геннадьевич', \\ OSavichev@mail.ru
}

\section{Рудмин Максим Андреевич 1 ,} RudminMA@tpu.ru

Мазуров Алексей Карпович',
AKM@tpu.ru

Федченко Артем Сергеевич', artem_fedchenk097@mail.ru

Рубан Алексей Сергеевич ${ }^{1}$, Ruban@tpu.ru

\author{
Даулетова Айгерим Бауыржановна' \\ Ikerimdb@gmail.com \\ 1 Национальный исследовательский Томский политехнический университет, \\ Россия, 634050, г. Томск, пр. Ленина, 30.
}

\begin{abstract}
Актуальность. Болота одновременно являются индикатором состояния окружающей среды в целом и связанных с болотами речных и подземных вод в частности. Это определяет необходимость изучения состояния болот, особенно в районе размещения крупных водозаборов, например, Томского подземного водозабора.

Цель: выявление изменений по глубине торффяной залежи Тимирязевского болота (западная окраина г. Томска, Западная Сибирь) химического состава торфов (кислотных вытяжек) и ассоциаций минеральных включений в торфяной залежи как индикаторов природно-антропогенных условий формирования болота.

Методы: методы определения химического (включая масс-спектрометрический с индуктивно связанной плазмой) и минерального состава (сканирующая электронная микроскопия с локальным энергодисперсионным анализом), статистические методы.

Результаты и выводы. Для переходного Тимирязевского болота в долине реки Томь у г. Томска выявлено неоднородное изменение зольности, Al, Ti, Cr и ряда других элементов с максимумами в верхней и нижней частях торффяной залежи пропорционально источнику минерального вещества (в верхней части залежи - пылевые выпадения, в нижней подстилающие грунты). С учетом данных, ранее полученных на Васюганском болоте, сделано предположение о наличии общего механизма формирования вещественного состава торфов и трансформации минерального вещества в болотах на основе фиильтрационньх свойств среды. Основные черты указанного выше механизма заключаются в биохимической трансформации минеральных веществ, поступающих из атмосфреры, с поверхностным и подземным стоком с суходолов, в результате чего в деятельном горизонте вещество находится во взвешенном, коллоидном и растворенном состоянии, а в инертном горизонте с большей интенсивностью формируются минеральные фазы. На поверхности последних, а также на частицах гидроокислов происходит соосаждение ряда микроэлементов и формирование аутигенных минералов, в том числе фоссратов редкоземельных элементов. Скорость и направленность этих процессов зависит от геоморфологических и гидрологических условий, определяющих возникновение и функционирование геохимических барьеров.
\end{abstract}

\section{Ключевые слова:}

Химический и минеральный состав, торфянная залежь, геохимия, Тимирязевское болото, город Томск, Западная Сибирь.

\section{Введение}

Торфяные болота представляют собой высоко динамичные осадочные системы за счёт большого количества реакционноспособного органического вещества, процессов взаимодействий в системе «вода - органическое вещество - порода», сезонных колебаний водности и, как следствие, флуктуаций хемоклина и геохимических условий [1-4]. Торф - это высокоорганический осадок от светло-коричневого до почти черного цвета, образующийся в заболоченных условиях в результате частичного разложения мхов и других мохообразных, осок, трав, кустарников или деревьев [2, 5]. С течением времени торф как осадок трансформируется в лигнит и уголь, в которых про- исходит накопление ряда химических элементов, включая редкоземельные [6, 7]. По этой причине изучение условий концентрирования металлов и накопления минералов в торфяной залежи является фундаментальным научным вопросом для понимания закономерностей формирования геохимического облика лигнитов и углей, в том числе глинистых и алевролитовых прослоев в этих толщах [1, 7-15].

Западная Сибирь характеризуется очень высокой заболоченностью, превышающей в отдельных водосборах $60 \%$ [16-18], причем болота повсеместно занимают часть речных долин, в том числе и на прилегающих территориях Саяно-Алтайской горной страны. Это обстоятельство обусловливает возможность 
поступления в реки и гидравлически связанные с ними подземные воды органических веществ и продуктов их трансформации, что сказывается на качестве вод и определяет актуальность исследований долинных и пойменных болот вблизи источников хозяйственно-питьевого водоснабжения

В данной работе исследуется болото, расположенное в 2 км на юго-запад от п. Тимирязево и 3,5 км на запад от г. Томска $[19,20]$. Далее используется условное название «Тимирязевское болото». Оно расположено одновременно в зоне потенциального влияния первой очереди Томского водозабора подземных вод и в зоне ветрового переноса загрязняющих веществ от автотранспорта и предприятий г. Томска и Томского района [20-24]. Цель исследования - выявление изменений по глубине торфяной залежи химического состава торфов (кислотных вытяжек) и ассоциаций минеральных включений в торфяной залежи как индикаторов условий формирования торфов в природно-антропогенных условиях. В фундаментальном отношении рассматриваемые усло- вия характеризуются сочетанием: 1) влияния гумидного и достаточно сурового климата; 2) расположения на границе Западно-Сибирской равнины и ее палеозойского обрамления; 3) высокой амплитудой колебаний уровней речных вод (свыше 10 м); 4) функционирования одного из крупнейших в Российской Федерации подземного водозабора; 5) атмосферного загрязнения от полумиллионного города.

\section{Объект и методика исследования}

Объект исследования - Тимирязевское болото, расположенное в левобережной части долины р. Томи на аллювиальных (песчаных, супесчаных и суглинистых) отложениях второй надпойменной террасы р. Томи (рис. 1). Болото мезотрофное сфагновокустарничково-сосновое, с глубинами торфяной залежи 1,0-4,8 м. Верхняя часть залежи в центральной части болота сложена верховым и переходным торфами, средняя и нижняя части - низинными торфами $[20,25]$. Более подробная информация об этом объекте изложена в [19, 20, 25].

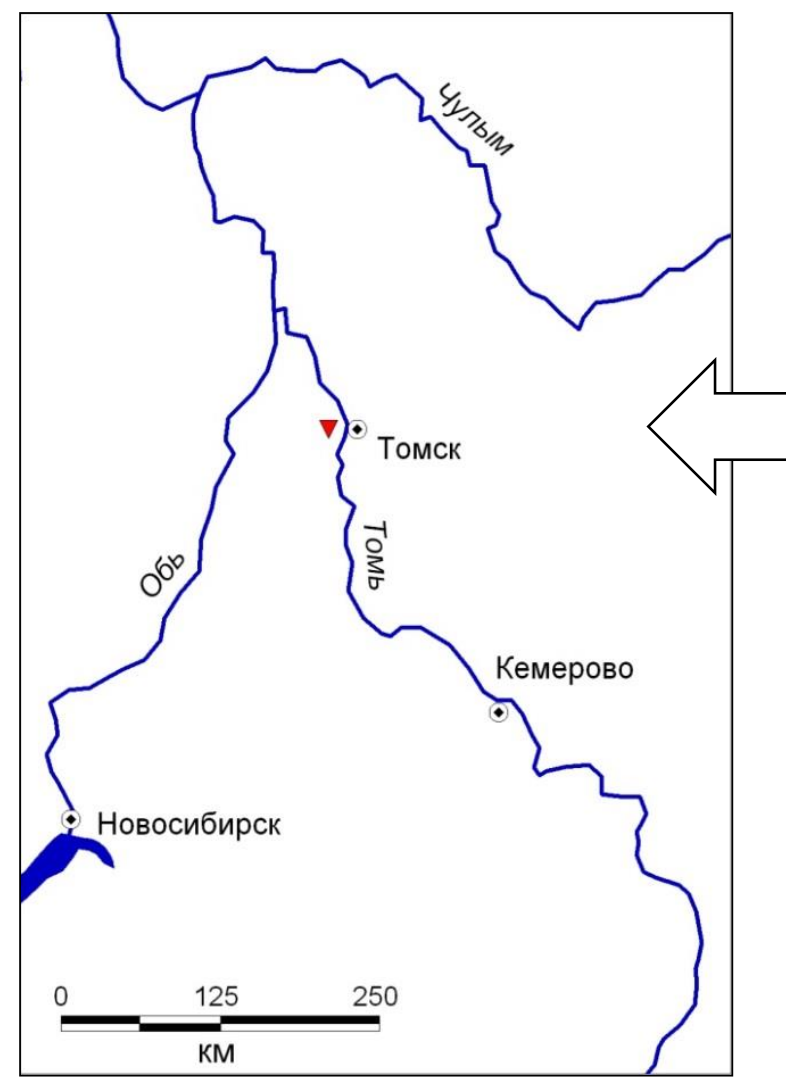

Методика исследования включала в себя:

1) отбор (25 ноября 2019 г., при наличии снегового покрова) проб торфа, органоминеральных отложений (OMO) и минерального грунта через 0,25 м в трех скважинах: I - координаты $56,4572^{\circ}$ с.ш., $84,8667^{\circ}$ в.Д., глубина торфяной залежи 4,25 м; II координаты $56,4577^{\circ}$ с.ш., $84,8662^{\circ}$ в.д., глубина торфяной залежи 3,25 м; III - координаты 56,4581 ${ }^{\circ}$ с.ш., $84,8660^{\circ}$ в.д., глубина торфяной залежи 3,40 м согласно [26, 27]; дополнительно в деятельном горизонте торфяной залежи (верхний

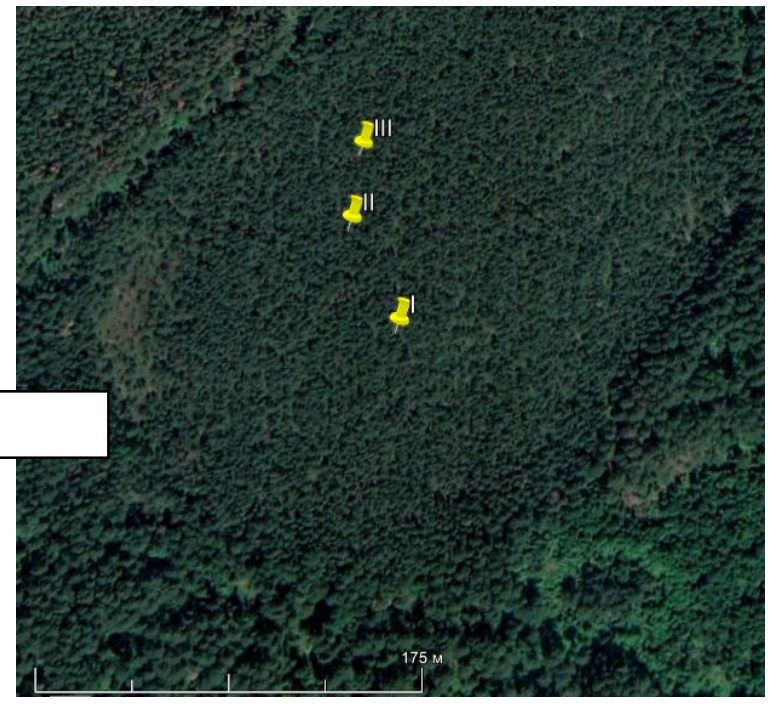

Pис. 1. Схема размещения пунктов наблюдений за химическим составом вод и торфов Тимирязевского болота у г. Томска (снимок Google Earth по состоянию на 23.06.2020; пробы торфа отобраны 25.11.2019)

Fig. 1. Schematic location map with sampling points in the Timiryazevo mire near the Tomsk city (Google Earth-image at 23.06.2020; peat was collected on 25.11.2019)

слой около 0,3-0,4 от отметки средней поверхности болота) в трех скважинах были отобраны пробы болотных вод;

2) определение химического состава кислотных вытяжек из торфов и болотных вод в аккредитованной гидрогеохимической лаборатории ТПУ; кислотная вытяжка получена из предварительно высушенных образцов пробы (доведение проб до воздушно-сухого состояния, растирание в фарфоровой ступке, прогревание в микроволновой печи в течение 10 мин без закипания навески $0,2-0,5$ г в 
полиэтиленовой пробирке с добавлением 3 мл азотной кислоты; доведение полученного раствора деионизированной водой до 50 мл; более подробно методика изложена в [28]); анализ химического состава выполнен с использованием массспектрометрического метода с индуктивно связанной плазмой (масс-спектрометр NexION 300D); в водных вытяжках (доведение проб до воздушносухого состояния, растирание в фарфоровой ступке, перемешивание в круглодонной колбе в течение 3 мин навески 50-100 г с добавлением деионизированной воды, центрифугирование в течение 5 мин [28]) проведено определение $\mathrm{pH}$ и удельной электропроводности $\chi$; в болотных водах определены значения $\mathrm{pH}, \chi$, перманганатной окисляемости (ПО), концентрации $\mathrm{NO}_{3}^{-}, \mathrm{NO}_{2}^{-}$и $\mathrm{NH}_{4}^{+}$; методики определения компонентов химического состава болотных вод указаны в [28];

3) определение минерального состава включений в торфе, выполненное в ТПУ методом сканирующей электронной микроскопии (СЭМ), рентгенодифракционного анализа (РДА) и рамановской спектроскопии; СЭМ осуществлялся с использованием микроскопа TESCAN VEGA 3 SBU, оснащенного приставкой для рентгенофлуоресцентного энергодисперсионного анализа (ЭДС) OXFORD X-Max 50; РДА - с использованием дифрактометpa Rigaku Ultima IV; Раман-спектроскопия - с использованием дисперсионного конфокального микроскопа комбинационного рассеяния Thermo Fisher Scientific DXR2 Raman [29]; зольность определена с учетом требований [30], более подробная информация - в [29];

4) статистический анализ полученных данных, включавший расчет среднего, дисперсии, коэффициентов корреляции, проверку на экстремумы и поиск регрессионных зависимостей с учетом требований [31]; корреляционные связи принимались статистически значимыми (с уровнем значимости $5 \%$ при соблюдении условия $|r| \geq \frac{2\left(1-r^{2}\right)}{\sqrt{N-2}} \quad$ и $|r| \geq 0,70$, а регрессионные - при условии $R^{2}>0,36$ и $\left|k_{r}\right| \geq \delta_{k}$, где $r$ - коэффициент корреляции; $k_{r}-$ коэффициент регрессии; $\delta_{k}$ - погрешность определения коэффициента регрессии; $N$ - объем выборки; $R^{2}$ - квадрат корреляционного отношения. Расчеты выполнены в пакете MS Excel.

\section{Результаты исследования и их обсуждение}

Зольность торфов $A$ (отношение оставшейся после прокаливания массы минеральной части торфа к массе сухого торфа, \% [5]) Тимирязевского болота изменяется в диапазоне $1,3 \ldots 10,5$ \% при среднем значении $2,2 \%$. Распределение по глубине характеризуется максимальным значениями $A$ (до $10,5 \%$ ) в деятельном горизонте части торфяной залежи в слое $0 . .0,25$ м, примерно равномерным распределением в ее средней части и контрастным закономерным увеличением зольности ОМО на границе торфяной залежи и мине- ральных грунтов (рис. 2). Диапазон колебания влаги торфов $w$ составляет 79,6...94,1 \%, ОМО - около $70 \%$, минеральных грунтов - 24,9 ..46,0 \% ( $w$ - влага торфа или влажность торфа - массовая доля влаги в торфе [5]). Изменение влаги по глубине в целом обратно пропорционально зольности - для торфов коэффициент корреляции с зольностью $A$ составляет минус $0,51 \pm 0,12$ (табл. 1 ).

С использованием комплекса методов (СЭМ, РДА и рамановская спектроскопия) в разрезе торфяной залежи было выявлено около 24 минеральных фаз в составе торфа, ОМО и базальных отложений, в том числе кварц, полевые шпаты (микроклин, альбит, анортит), рутил, ильменит, магнетит, хромит, циркон, монацит, апатит, пироксены, иллит, каолинит, смектит, окислы и гидроокислы железа (ферригидрид), гиббсит, карбонаты (кальцит, магниевый кальцит и доломит), пирит, халькопирит, гипс, барит, висмутин, фосфат Р3Э и фаза $\mathrm{Cu}-\mathrm{Zn}$. Атмосферный аэрозоль, отобранный в пределах исследуемого болота, содержал частицы следующих минералов: кварц, альбит, рутил, магнетит, ильменит, диопсид.

Окислы и гидроокислы железа прослеживаются в торфяной залежи до глубины 4,5 м. Они образуют микрозёрна (рис. $3, a, б$ ) полусферической формы размером от 0,1 до 8,0 мкм. В этих микровключениях имеются типичные примеси $\mathrm{Al}, \mathrm{Si}$ и в меньшей мере $\mathrm{P}$. Их значительное количество отмечается в ОМО и подстилающих суглинках. Гиббсит или другие окислы и гидроокислы алюминия, так же как и железистые гидрооксидные фазы, накапливаются в средних и нижних слоях торфяной толщи. Для гиббсита характерны полусферические и реже слабо вытянутые зёрна размером до 4 мкм (рис. 3, в). В качестве примеси в них отмечается $\mathrm{Si}$ до $8 \%$.

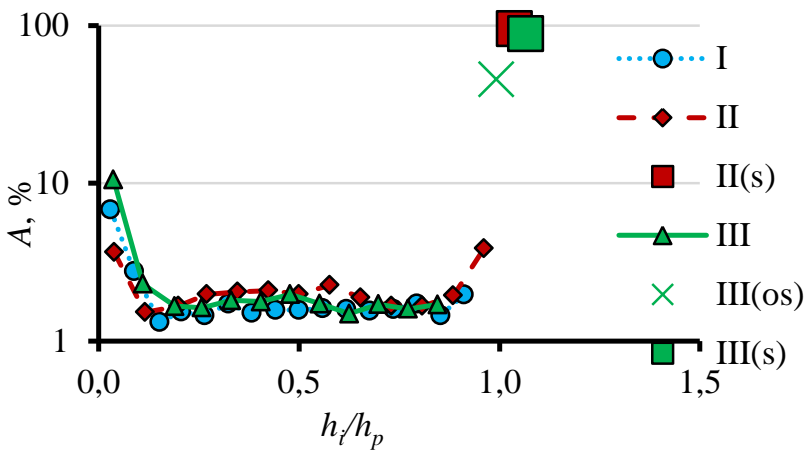

Pис. 2. Изменение значений зольности торфов $A(\%)$ в зависимости от относительной глубины $h_{i} / h_{p} 6$ скважсинах I, II, III (рис. 1); $h_{i}$ - средняя глубина i-интервала опробования (через $0,25 \mathrm{M}$ ); $h_{p}$ верхняя граница залегания минерального грунта; индексы «s» $и$ «оs» соответствуют минеральному грунту (суглинок) и органоминеральным отложениям

Fig. 2. Change of peat ash values $A$ depending on relative depth $h_{i} / h_{p}$ in I, II, III wells (Fig. 1$) ; h_{i}$ - average depth of $i$-interval of samples (through $0,25 \mathrm{~m}$ ); $h_{p}-$ top border of a basal loams; indexes «s» and «os» correspond to a basal loam and organomineral sediments 
Таблица 1. Физико-химические показатели торфов и химический состав кислотных вытяжек из проб грунта на Тимирязевском болоте

Table 1. Physical and chemical parameters of peats and chemical composition of acid extracts from samples in the Timiryazevo mire

\begin{tabular}{|c|c|c|c|c|c|c|c|c|c|c|c|c|c|c|c|c|c|c|}
\hline \multirow[b]{2}{*}{ № } & \multirow{2}{*}{$\begin{array}{l}\text { Интервал } \\
\text { глубин, м } \\
\text { Depth } \\
\text { interval, m }\end{array}$} & \multirow{2}{*}{ 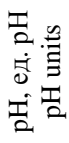 } & \multirow{2}{*}{ 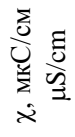 } & \multirow[b]{2}{*}{$A, \%$} & $\mathrm{Ca}$ & $\mathrm{Na}$ & K & $\mathrm{Cl}$ & $\mathrm{Si}$ & $\mathrm{P}$ & $\mathrm{Al}$ & $\mathrm{Fe}$ & $\mathrm{Ti}$ & $\mathrm{Zn}$ & $\mathrm{Cd}$ & $\mathrm{La}$ & $\mathrm{Ce}$ & $\mathrm{Pb}$ \\
\hline & & & & & \multicolumn{14}{|c|}{$\begin{array}{c}\mathrm{Mг} / \mathrm{Kг} \\
\mathrm{mg} / \mathrm{kg}\end{array}$} \\
\hline \multirow[t]{17}{*}{1} & $0,00 \ldots 0,25$ & 3,56 & 192 & 6,8 & 2182,5 & 53,0 & 259,6 & 1079,2 & 112,1 & 352,7 & 2153,6 & 2730,9 & 37,7 & 16,5 & 0,11 & 2,09 & 4,42 & 26,68 \\
\hline & $0,25 \ldots 0,50$ & 3,39 & 131 & 2,8 & 1876,4 & 78,3 & 76,4 & 1125,8 & 130,6 & 150,3 & 852,3 & 478,2 & 13,9 & 13,9 & 0,08 & 0,56 & 1,00 & 1,59 \\
\hline & $0,50 \ldots 0,75$ & 3,38 & 135 & 1,3 & 2052,7 & 102,2 & 80,2 & 1202,8 & 152,9 & 119,8 & 719,4 & 700,0 & 12,7 & 16,2 & 0,07 & 0,46 & 0,85 & 1,46 \\
\hline & $0,75 \ldots 1,00$ & 3,78 & 142 & 1,5 & 2211,4 & 63,3 & 49,1 & 787,4 & 162,7 & 101,2 & 802,9 & 643,0 & 13,6 & 41,8 & 0,05 & 0,45 & 0,72 & 1,22 \\
\hline & $1,00 \ldots 1,25$ & 3,83 & 115 & 1,5 & 2043,3 & 73,5 & 47,0 & 1038,6 & 179,3 & 90,9 & 803,7 & 596,1 & 13,0 & 68,8 & 0,06 & 0,40 & 0,67 & 1,24 \\
\hline & $1,25 \ldots 1,50$ & 3,89 & 110 & 1,7 & 2175,7 & 74,7 & 48,3 & 1213,9 & 179,9 & 104,6 & 786,1 & 601,0 & 14,5 & 70,1 & 0,05 & 0,44 & 0,77 & 1,29 \\
\hline & $1,50 \ldots 1,75$ & 3,70 & 84 & 1,5 & 2340,1 & 112,0 & 80,1 & 1043,5 & 190,3 & 84,2 & 824,9 & 667,9 & 14,3 & 87,2 & 0,05 & 0,41 & 0,75 & 1,19 \\
\hline & $1,75 \ldots 2,00$ & 3,84 & 105 & 1,6 & 2337,3 & 73,2 & 57,5 & 1323,7 & 202,4 & 103,0 & 863,5 & 700,1 & 14,5 & 97,5 & 0,05 & 0,44 & 0,77 & 1,37 \\
\hline & $2,00 \ldots 2,25$ & 3,94 & 87 & 1,6 & 2144,1 & 67,7 & 57,1 & 1051,6 & 150,9 & 77,2 & 722,3 & 537,7 & 12,5 & 96,0 & 0,05 & 0,34 &, 54 & 0,96 \\
\hline & $2,25 \ldots 2,50$ & 3,61 & 91 & 1,6 & 2111,1 & 105,3 & 68,8 & 1377,9 & 222,6 & 118,0 & 907,0 & 885,6 & 15,2 & 138,8 & 0,06 & 57 &, 06 & 1,27 \\
\hline & $2,50 \ldots 2,75$ & 3,68 & 125 & 1,6 & 1650,1 & 186,9 & 77,1 & 2031,4 & 150,7 & 106,3 & 727,7 & 689,6 & 13,1 & 193,9 & 0,05 & 0,46 & 0,90 & 1,00 \\
\hline & $2,75 \ldots 3,00$ & 3,95 & 121 & 1,5 & 2218,3 & 83,9 & 58,6 & 1845,4 & 165,0 & 95,4 & 679,3 & 774,3 & 11,6 & 284,2 & 0,05 & 0,43 & 0,83 & 1,27 \\
\hline & $3,00 \ldots 3,25$ & 3,55 & 111 & 1,6 & 1968,6 & 107,5 & 64,7 & 1451,4 & 186,5 & 120,8 & 896,4 & 920,8 & 14,3 & 390,6 & 0,06 & 0,46 & 0,97 & 2,28 \\
\hline & $3,25 \ldots 3,50$ & 3,79 & 126 & 1,7 & 1889,3 & 103,6 & 66,0 & 1888,9 & 175,5 & 119,1 & & 928,6 & 14,2 & 390,1 & 0,06 & 0,48 & 0,97 & 1,48 \\
\hline & $3,50 \ldots 3,75$ & 3,74 & 128 & 1,5 & 2340,6 & 295,5 & 87,5 & 295 & 189,2 & 118,9 & & 926,4 & 13,4 & 463,9 & 0,06 & & 0,91 & 1,19 \\
\hline & $3,75 \ldots 4,00$ & 3,62 & 124 & 2,0 & 2669,8 & 152,1 & 83,1 & 2378,7 & 220,9 & 117,0 & 875,9 & 1008,5 & 15,5 & 787,1 & 0,05 & 55 & 1,00 & 1,90 \\
\hline & $4,00 \ldots 4,25$ & 3,85 & 93 & - & 3333,0 & 121,5 & 88,4 & 1890,3 & 229,3 & 166,8 & 995,1 & 1006,8 & 16,7 & 769,9 & 0,08 & & 1,06 & 2,46 \\
\hline \multirow[t]{13}{*}{2} & $0,00 \ldots 0,25$ & 3,31 & 172 & 3,7 & 1296,2 & 64,8 & 425,9 & 1320,6 & 135,5 & 348,3 & 2551,1 & 2667,7 & 36,2 & 32,1 & 0,32 & 2,97 & 81 & 16,39 \\
\hline & $0,25 \ldots 0,50$ & 3,53 & 100 & 1,5 & 1492,0 & \begin{tabular}{|l|}
58,4 \\
\end{tabular} & 59,9 & 2380,2 & 169,8 & 186,3 & 911,0 & 466,1 & 15,6 & 25,7 & 0,06 & 0,44 & 1,22 & 1,26 \\
\hline & $0,50 \ldots 0,75$ & 3,44 & 129 & 1,7 & 1357,0 & 120,6 & 89,6 & 2071,1 & 167,5 & 132,9 & 943,9 & 599,5 & 14,7 & 8,4 & 0,07 & 0,47 & 1,19 & 1,39 \\
\hline & $0,75 \ldots 1,00$ & 3,42 & 110 & 2,0 & 1497,7 & 98,6 & 90,0 & 208 & 160,4 & 155,1 & & 0,9 & 16,4 & 14,9 &, 05 & & 30 & 1,92 \\
\hline & $1,00 \ldots 1,25$ & 3,55 & 119 & 2,1 & 1186,0 & 100,2 & 79,3 & 1363,7 & 122,2 & 130,2 & 743 & 517,9 & 12,9 & 14,9 & 0,04 & 0,39 & 0,77 & 1,63 \\
\hline & $1,25 \ldots 1,50$ & 3,74 & 120 & 2,1 & 1562,6 & \begin{tabular}{|l|}
91,7 \\
\end{tabular} & 69,6 & 2250,7 & 156,6 & 177,0 & 994,5 & 645,0 & 18,6 & 16,1 & 0,05 & 0,50 & 1,06 & 1,40 \\
\hline & $1,50 \ldots 1,75$ & 3,86 & 95 & 2,0 & 1482,0 & 89,9 & 73,1 & 1540,6 & 162,4 & 150,5 & 1020,0 & 654,2 & 19,7 & 27,0 & 0,04 & 0,49 & 1,06 & 1,27 \\
\hline & $1,75 \ldots 2,00$ & 3,64 & 92 & 2,3 & 1667,5 & 99,3 & 84,1 & 1619,0 & 203,7 & 133,2 & 806,4 & 673,4 & 15,5 & 45,4 & 0,06 & 0,37 & 0,82 & 1,00 \\
\hline & $2,00 \ldots 2,25$ & 3,60 & 111 & 1,9 & 1473,3 & 90,8 & 78,5 & 2141,0 & 163,7 & 135,6 & 817,1 & 608,6 & 15,8 & 52,5 & 0,05 & 0,39 & 0,78 & 1,05 \\
\hline & $2,25 \ldots 2,50$ & 3,67 & 117 & 1,7 & 1618,6 & 96,2 & 80,5 & 3220,8 & 220,4 & 126,3 & & 573,0 & 15,9 & 60,4 & 0,06 & 38 & 0,79 & 0,96 \\
\hline & $2,50 \ldots 2,75$ & 3,98 & 78 & 1,7 & 160 & 95,8 & 72,7 & 173 & 189,4 & 157,4 & & 88,4 & 18,3 & 69,8 & 0,05 & & 1,00 & 0,84 \\
\hline & $2,75 \ldots 3,00$ & 4,12 & 77 & 1,9 & 1695,3 & 101,7 & 97,0 & 1511,1 & 182,8 & 136,9 & 978,6 & 685,7 & 17,1 & 170,7 & 0,06 & 0,50 & 1,08 & 1,26 \\
\hline & $3,00 \ldots 3,25$ & 4,71 & 48 & 3,9 & 1614,3 & 72,1 & 85,2 & 1919,7 & 128,4 & 230,6 & 1688,8 & 923,5 & 29,3 & 48,1 & 0,06 & 1,10 & 2,66 & 1,10 \\
\hline $2^{* *}$ & $3,25 \ldots 3,50$ & 5,06 & 38 & 94,9 & 362,8 & 14,1 & 83,7 & 519,8 & 32,9 & 136,8 & 978,2 & 880,6 & 28,1 & 6,8 & 0,01 & 45 & 3,07 & 2,02 \\
\hline \multirow[t]{13}{*}{3} & $0,00 \ldots 0,25$ & 4,03 & 84 & 10,5 & 1661,4 & 38,9 & 101,8 & 1612,4 & 143,3 & 191,2 & 1357,5 & 1015,7 & 21,0 & 13,0 & 0,09 & 0,78 & 1,71 & 10,95 \\
\hline & $0,25 \ldots 0,50$ & 3,91 & 94 & 2,3 & 1961,9 & 62,4 & 57,8 & 1233,2 & 112,3 & 144,4 & 704,0 & 491,2 & 12,1 & 16,7 & 0,05 & 0,45 & 0,96 & 1,46 \\
\hline & $0,50 \ldots 0,75$ & 3,95 & 95 & 1,7 & 1967,7 & 76,4 & 92,9 & 770,0 & 81,1 & 140,4 & & 501,6 & 12,7 & 15,2 & 0,05 & 0,42 & 0,79 & 1,94 \\
\hline & $0,75 \ldots 1,00$ & 4,11 & 75 & 1,6 & 2186,8 & 94,7 & 107,9 & 856,8 & 120,3 & 160,3 & & 557,0 & 13,2 & 26,7 & 0,04 & 0,46 & 0,91 & 1,35 \\
\hline & $1,00 \ldots 1,25$ & 4,03 & 84 & 1,8 & 2457,3 & 148,0 & 168,3 & 1290,1 & 141,9 & 161,9 & 970 & 587,6 & 14,9 & 23,7 & 0,0 & & 0,93 & 1,41 \\
\hline & $1,25 \ldots 1,50$ & 3,95 & 110 & 1,8 & 2046,3 & 81,3 & 78,7 & 651,7 & 128,1 & 118,0 & 785,4 & 560,0 & 12,2 & 50,6 & 0,04 & 0,34 & 0,67 & 1,03 \\
\hline & $1,50 \ldots 1,75$ & 3,91 & 88 & 2,0 & 2358,8 & 102,1 & 97,2 & 1166,6 & 174,1 & 146,3 & 854,3 & 680,2 & 16,4 & 41,1 & 0,06 & 0,52 & 1,04 & 1,72 \\
\hline & $1,75 \ldots 2,00$ & 3,89 & 94 & 1,7 & 2551,8 & 110,5 & 114,1 & 915,1 & 140,7 & 142,1 & 892,6 & 687,2 & 14,7 & 110,5 & 0,05 & 0,46 & 0,90 & 1,63 \\
\hline & $2,00 \ldots 2,25$ & 3,94 & 102 & 1,5 & 2159,3 & 83,5 & 77,8 & 955,5 & 173,3 & 155,7 & 862,6 & 691,3 & 16,1 & 151,5 & 0,06 & 0,45 & 0,78 & 1,59 \\
\hline & $2,25 \ldots 2,50$ & 4,01 & 71 & 1,7 & 2422,9 & 88,5 & 82,8 & 875,0 & 135,5 & 124,5 & 826,0 & 655,6 & 13,6 & 158,3 & 0,05 & 0,41 & 0,82 & 1,22 \\
\hline & $2,50 \ldots 2,75$ & 4,07 & 67 & 1,6 & 2352,3 & 82,6 & 86,4 & 978,3 & 134,8 & 123,2 & 777,4 & 676,3 & 14,1 & 111,4 & 0,04 & 0,38 & 0,74 & 0,83 \\
\hline & $2,75 \ldots 3,00$ & 4,37 & 82 & 1,7 & 3740,4 & 90,9 & 103,0 & 869,8 & 145,6 & 155,3 & 722,1 & 1199,4 & 13,3 & 108,0 & 0,05 & 0,35 & 0,75 & 0,74 \\
\hline & $3,00 \ldots 3,25$ & 4,16 & 34 & - & 3412,3 & 108,7 & 93,2 & 1250,2 & 164,4 & 127,5 & & 817,7 & 13,7 & 281,0 & 0,05 & & 0,82 & 0,90 \\
\hline $3 *$ & $3,25 \ldots 3,50$ & 4,83 & 34 & 45,3 & 3860,3 & 57,5 & 86,2 & 1180,5 & 141,3 & 428,1 & 3112,3 & 3279,4 & 47,1 & 47,4 & 0,54 & 2,33 & 5,39 & 1,59 \\
\hline $3^{* *}$ & $3,50 \ldots 3,75$ & 5,01 & 33 & 88,3 & 1245,5 & 10,8 & 305,6 & 125,0 & 175,6 & 511,9 & 3936,1 & 2758,3 & 58,4 & 15,8 & 0,10 & 3,16 & 6,14 & 3,68 \\
\hline
\end{tabular}

Примечание: * органоминеральные отложения; ** минеральный грунт (суглинок); в прочих случаях - торф; $\chi-$ удельная электропроводность; $A$ - зольность.

Note: * organomineral sediments; ** basal loams; peat samples are in other cases; $\chi-$ specific electric conductivity; $A-$ peat ash.

Пирит $\left(\mathrm{FeS}_{2}\right)$ встречается в основном в ассоциации с карбонатными микровключениями в средней и нижней части торфяной залежи. Размер микрокристаллитов пирита не превышает 5 мкм. Карбонаты представлены кальцитом, магниевым кальцитом и доломитом. Кальцит преобладает относительно доломита. Максимальное концентрирование карбонатов (рис. $3,2, ж-u$ ) отмечается в среднем слое торфяной залежи и слое, перекрывающем базальные отложения. Доломит накапливается в слое торфа $3,50 \ldots 3,75$ м в скважине из центральной части болота. Кальцит характеризуется кристаллами ксеноморфного или субидиоморфного обликов и концентрируется в структуре сфагновых тканей. Кальцит относится к магнезиальной разновидности. Доломит встречается редко в виде ромбоэдрических кристаллов размером до 20 мкм (рис. 3 , ж). 

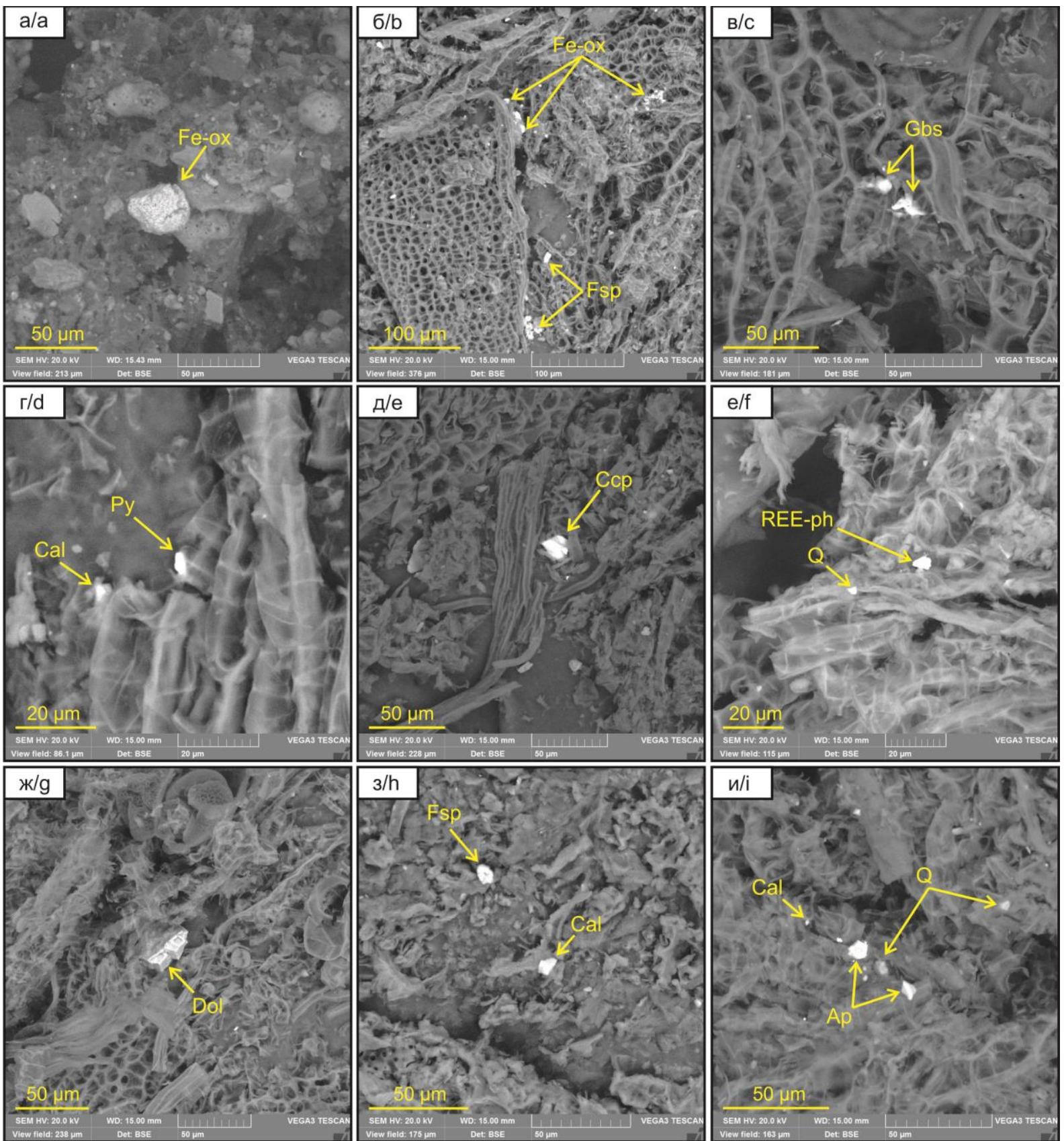

Рис. 3. Снимок минеральных включений в торфе, в ОМО и минеральном грунте на Тимирязевском болоте: a, б) окисль и гидроокисль железа (Fe-ох) в виде микросферул; в) гиббсит (Gbs); г) пирит (Py) и кальиит (Cal); д) халькопирит (Ccp); е) фосфат редкоземельных элементов (REE-ph) и детритовый квари (Q); ж) доломит (Dol); з) кальцит и терригенный полевой шпат (Fsp); и) кальцит с терригенными апатитом (Ар) и кварием. Изображения в детекторе обратнорассеянных электронов

Fig. 3. Picture of mineral inclusions in peat, organomineral sediments and basal loams in the Timiryazevo mire: $a, b)$ oxides and hydrooxides of iron (Fe-ox) as microspherules; c) gibbsite (Gbs); d) pyrite (Py) and calcite (Cal); e) chalcopyrite (Ccp); f) phosphate of rare earth elements (REE-ph) and detritus quartz $(Q) ; g)$ dolomite (Dol); $h$ ) calcite with terrigenous feldspar (Fsp); i) calcite with terrigenous apatite (Ap) and quartz. Images in the backscattered electron detector

Анализ ранее полученных материалов показал, что воды Тимирязевского болота в целом кислые и слабокислые, пресные с минерализацией от очень малой до средней, содержат большое количество органических веществ, по химическому составу в среднем сульфатные кальциевые [19, 20]. В разрезе торфяной залежи минимальные значения содержаний главных ионов и рН отмечаются в среднем в деятельном гори- зонте, во временном разрезе максимальные значения выявлены либо в весенний период при поступлении микроэлементов, биогенных и органических веществ в болото с поверхностным стоком с прилегающих суходолов, с атмосферными осадками, при растворении твёрдых примесей талыми водами, либо в летний период - при усилении биогеохимических процессов и накоплении в водной среде главных ионов [19]. 
Таблица 2. Химический состав болотных вод и вытяжек из торфов в интервале глубин 0,00-0,25 м в скважинах I, II, III (puc. 1)

Table 2. Chemical composition of mire waters and extracts from peats in a depth interval of 0,00-0,25 $\mathrm{m}$ in I, II, III wells (Fig. 1)

\begin{tabular}{|c|c|c|c|c|c|c|}
\hline \multirow{3}{*}{ Показатель/Index } & \multicolumn{6}{|c|}{ Скважина (рис. 1)/Well (Fig. 1) } \\
\hline & \multicolumn{2}{|r|}{ I } & \multicolumn{2}{|c|}{ II } & \multicolumn{2}{|r|}{ III } \\
\hline & $\begin{array}{c}\text { Вода } \\
\text { Water }\end{array}$ & $\begin{array}{c}\text { Вытяжка из торфа } \\
\text { Extract from peat }\end{array}$ & $\begin{array}{c}\text { Вода } \\
\text { Water }\end{array}$ & $\begin{array}{c}\text { Вытяжка из торфа } \\
\text { Extract from peat }\end{array}$ & $\begin{array}{c}\text { Вода } \\
\text { Water }\end{array}$ & $\begin{array}{c}\text { Вытяжка из торфа } \\
\text { Extract from peat }\end{array}$ \\
\hline $\begin{array}{c}\text { pH, ед. } \mathrm{pH} \\
\text { pH units }\end{array}$ & 3,91 & $3,56^{*}$ & 3,93 & $3,31^{*}$ & 3,88 & $4,03 *$ \\
\hline$\chi$, мкС $/ \mathrm{cm} / \mu \mathrm{S} / \mathrm{cm}$ & 114 & $192 *$ & 105 & $172 *$ & 102 & $84 *$ \\
\hline $\begin{array}{l}\Pi \mathrm{O}, \mathrm{M \Gamma O} / \text { дм }^{3} \\
\mathrm{PO}, \mathrm{mgO} / \mathrm{dm}^{3}\end{array}$ & 808,00 & - & 392,00 & - & 380,00 & - \\
\hline & $\begin{array}{l}\mathrm{M \Gamma} / \mathrm{дM}^{3} \\
\mathrm{mg} / \mathrm{dm}^{3} \\
\end{array}$ & $\begin{array}{l}\mathrm{M} \Gamma / \mathrm{K \Gamma} \\
\mathrm{mg} / \mathrm{kg}\end{array}$ & $\begin{array}{c}\mathrm{M} \Gamma / д \mathrm{M}^{3} \\
\mathrm{mg} / \mathrm{dm}^{3}\end{array}$ & $\begin{array}{l}\mathrm{M \Gamma} / \mathrm{K \Gamma} \\
\mathrm{mg} / \mathrm{kg}\end{array}$ & $\begin{array}{l}\mathrm{M \Gamma} / \mathrm{дM}^{3} \\
\mathrm{mg} / \mathrm{dm}^{3}\end{array}$ & $\begin{array}{l}\mathrm{M \Gamma} / \mathrm{K \Gamma} \\
\mathrm{mg} / \mathrm{kg}\end{array}$ \\
\hline $\mathrm{Ca}$ & 3,44 & 2182,52 & 2,93 & 1296,20 & 2,70 & 1661,43 \\
\hline $\mathrm{Mg}$ & 1,43 & 398,03 & 1,56 & 580,74 & 1,09 & 510,38 \\
\hline $\mathrm{Na}$ & 0,80 & 53,02 & 1,02 & 64,84 & 0,75 & 38,93 \\
\hline $\mathrm{K}$ & 0,92 & 259,64 & 0,58 & 425,90 & 0,56 & 101,81 \\
\hline $\mathrm{S}$ & 2,50 & 838,79 & 2,42 & 1099,78 & 2,52 & 993,44 \\
\hline $\mathrm{Cl}$ & 1,79 & 1079,18 & 0,97 & 1320,59 & 1,21 & 1612,43 \\
\hline $\mathrm{NO}_{3}^{-}$ & 0,085 & - & 0,022 & - & 0,014 & - \\
\hline $\mathrm{NO}_{2}^{-}$ & 0,011 & - & 0,009 & - & 0,000 & - \\
\hline $\mathrm{NH}_{4}^{+}$ & 9,800 & - & 11,000 & - & 15,000 & - \\
\hline $\mathrm{P}$ & 0,225 & 352,656 & 0,398 & 348,282 & 0,178 & 191,224 \\
\hline $\mathrm{Si}$ & 7,874 & 112,073 & 9,494 & 135,511 & 6,577 & 143,347 \\
\hline $\mathrm{Fe}$ & 1,116 & 2730,947 & 1,060 & 2667,745 & 0,854 & 1015,719 \\
\hline $\mathrm{Al}$ & 1,376 & 2153,642 & 1,595 & 2551,082 & 0,939 & 1357,535 \\
\hline & $\begin{array}{l}\text { мкг/дм }{ }^{3} \\
\mathrm{mg} / \mathrm{dm}^{3}\end{array}$ & $\begin{array}{l}\mathrm{M \kappa} \Gamma / \mathrm{K} \Gamma \\
\mathrm{mg} / \mathrm{kg}\end{array}$ & $\begin{array}{l}\text { мкг/дм }{ }^{3} \\
\mathrm{mg} / \mathrm{dm}^{3}\end{array}$ & $\begin{array}{l}\mathrm{M \kappa г} / \mathrm{K} \Gamma \\
\mathrm{mg} / \mathrm{kg}\end{array}$ & $\begin{array}{l}\text { мкг/дм }{ }^{3} \\
\mathrm{mg} / \mathrm{dm}^{3}\end{array}$ & $\begin{array}{l}\mathrm{M \kappa} \Gamma / \mathrm{K} \Gamma \\
\mathrm{mg} / \mathrm{kg}\end{array}$ \\
\hline $\mathrm{Li}$ & 3,23 & 144,57 & 3,41 & 149,50 & 2,94 & 263,30 \\
\hline $\mathrm{Ti}$ & 29,38 & 37744,25 & 45,45 & 36151,64 & 23,39 & 20997,35 \\
\hline $\mathrm{V}$ & 3,22 & 4174,86 & 3,21 & 4870,99 & 2,87 & 2505,82 \\
\hline $\mathrm{Cr}$ & 3,10 & 4580,73 & 3,68 & 3465,59 & 2,55 & 2278,24 \\
\hline $\mathrm{Mn}$ & 30,16 & 18406,64 & 8,92 & 9134,82 & 49,68 & 28041,31 \\
\hline $\mathrm{Co}$ & 0,90 & 959,82 & 0,98 & 1683,29 & 0,65 & 638,29 \\
\hline $\mathrm{Ni}$ & 2,57 & 2717,09 & 2,83 & 3499,07 & 2,25 & 1733,64 \\
\hline $\mathrm{Cu}$ & 2,31 & 3563,57 & 2,03 & 5201,37 & 3,31 & 3221,65 \\
\hline $\mathrm{Zn}$ & 37,82 & 16517,24 & 50,27 & 32120,18 & 32,33 & 13017,34 \\
\hline As & 3,90 & 3475,23 & 3,25 & 3445,23 & 2,57 & 818,38 \\
\hline $\mathrm{Y}$ & 0,92 & 1489,50 & 0,97 & 1777,82 & 0,88 & 636,15 \\
\hline $\mathrm{Zr}$ & 1,67 & 2212,76 & 2,44 & 2593,10 & 1,71 & 1038,96 \\
\hline $\mathrm{Cd}$ & 0,09 & 114,55 & 0,08 & 316,74 & 0,05 & 91,13 \\
\hline $\mathrm{Ba}$ & 31,06 & 46406,19 & 33,81 & 43273,36 & 23,72 & 21126,01 \\
\hline $\mathrm{La}$ & 0,83 & 2090,83 & 0,79 & 2974,52 & 0,52 & 783,78 \\
\hline $\mathrm{Ce}$ & 1,48 & 4422,30 & 1,66 & 5805,43 & 1,02 & 1707,02 \\
\hline $\operatorname{Pr}$ & 0,16 & 509,89 & 0,19 & 610,94 & 0,12 & 182,94 \\
\hline $\mathrm{Nd}$ & 0,64 & 1865,03 & 0,71 & 2206,26 & 0,50 & 699,31 \\
\hline $\mathrm{Sm}$ & 0,16 & 351,67 & 0,15 & 526,13 & 0,15 & 148,72 \\
\hline $\mathrm{Eu}$ & 0,05 & 81,84 & 0,04 & 89,84 & 0,04 & 36,45 \\
\hline $\mathrm{Gd}$ & 0,22 & 402,13 & 0,20 & 489,12 & 0,17 & 150,78 \\
\hline $\mathrm{Tb}$ & 0,03 & 55,54 & 0,03 & 61,52 & 0,03 & 22,01 \\
\hline Dy & 0,20 & 283,63 & 0,20 & 353,75 & 0,20 & 121,26 \\
\hline Ho & 0,04 & 49,98 & 0,04 & 69,00 & 0,04 & 21,56 \\
\hline Er & 0,10 & 143,29 & 0,11 & 166,25 & 0,11 & 65,87 \\
\hline $\mathrm{Tm}$ & 0,01 & 17,99 & 0,02 & 22,36 & 0,01 & 9,28 \\
\hline $\mathrm{Yb}$ & 0,07 & 121,74 & 0,07 & 126,52 & 0,07 & 48,44 \\
\hline $\mathrm{Lu}$ & 0,01 & 15,51 & 0,01 & 19,55 & 0,01 & 7,45 \\
\hline Hf & 0,10 & 105,93 & 0,16 & 86,49 & 0,11 & 51,44 \\
\hline $\mathrm{W}$ & 0,11 & 488,77 & 0,19 & 602,39 & 0,12 & 180,42 \\
\hline $\mathrm{Hg}$ & 0,06 & 128,01 & 0,07 & 160,87 & 0,05 & 104,67 \\
\hline $\mathrm{Pb}$ & 1,58 & 26683,35 & 1,76 & 16385,13 & 0,92 & 10948,33 \\
\hline $\mathrm{Bi}$ & 0,02 & 149,88 & 0,03 & 175,60 & 0,01 & 44,61 \\
\hline
\end{tabular}

Примечание: * в водной вытяжке, в прочих случаях - кислотные вытяжки; $\chi$-удельная электропроводность; ПО перманганатная окисляемость.

Note: * in water extract, acid extracts are in other cases; $\chi$-specific electric conductivity; $P O$ - permanganate index of mire water. 
По состоянию на 25.11.2019 г. болотные воды также характеризовались как пресные, кислые, с высоким содержанием органических веществ по перманганатной окисляемости и содержанию ионов $\mathrm{NH}_{4}^{+}$. Водные вытяжки из слоя торфа 0,00...0,25 м характеризовались примерно такими же, как для болотных вод, значениями $\mathrm{pH}$ и удельной электропроводности, а кислотные вытяжки - существенно более высокими концентрациями всех изученных химических элементов (табл. 2). Максимальные значения удельной электропроводности болотных вод и водной вытяжки из торфа отмечены в верхнем слое $(0,00 \ldots 0,25$ м) в скважине I (рис. 1), где обнаружены наиболее высокое значение перманганатной окисляемости воды $(808$ мгО/дм³ $)$ и наименьшая влажность торфа (табл. 1, 2).

Согласно [9] и с учетом указанных выше фактов можно предположить, что накопление водорастворимых солей связано в основном с условиями разложения органического вещества в центре болота и накопления продуктов его трансформации. Второй источник - пылевые выпадения из атмосферного воздуха, которые вступают во взаимодействие с кислыми водами в деятельном горизонте торфяной залежи, а также выпадение из раствора малорастворимых соединений, образующихся из компонентов состава снеготалых и дождевых вод. Влияние притока веществ с суходолов вполне вероятно на окраине болота (скважина III), но вряд ли значимо в центре болота (скважины II и, особенно, I). Для более детальной проверки этой гипотезы требуются численные геомиграционные расчеты.

С глубиной влияние обоих факторов убывает, что сказывается на уменьшении в основной части торфяной залежи зольности торфов и концентраций ряда химических элементов в кислотных вытяжках и последующем их возрастании на границе торфяной залежи и минеральных грунтов (табл. 1). В числе химических элементов, распределение которых достаточно хорошо совпадает с изменением по глубине зольности торфов (статистически значимые коэффициенты корреляции более 0,70), присутствует $\mathrm{Al}$ (рис. 4), Ti, $\mathrm{Cr}$ и некоторые другие элементы.

Ранее авторами для олиготрофного восточного участка Васюганского болота был сделан вывод о том, что при разрушении минералов группы смектита, присутствующих в атмосферной пыли, в деятельный горизонт торфяной залежи поступает ряд химических элементов [28]. Уровень их содержания как в деятельном, так и в инертном горизонтах торфяной залежи в последующий период определяется биоаккумуляцией и способностью образовывать с органическими веществами соединения с различной миграционной способностью и растворимостью. Эти процессы, в свою очередь, связаны с болотной микрофлорой. В частности, прослеживается связь между присутствием в минеральных включениях гидроокислов железа и активностью железобактерий, а также возрастание вероятности накопления в торфах малорастворимых соединений кальция по мере усиления анаэробных условий и связанного с этим увеличением $\mathrm{pH}$ болотной среды. Вследствие сорбционных процессов на гидроокислах железа и малорастворимых соединениях кальция происходит осаждение соединений ряда других химических элементов, причем этот процесс усиливается в нижних слоях торфяной залежи [28, 29].

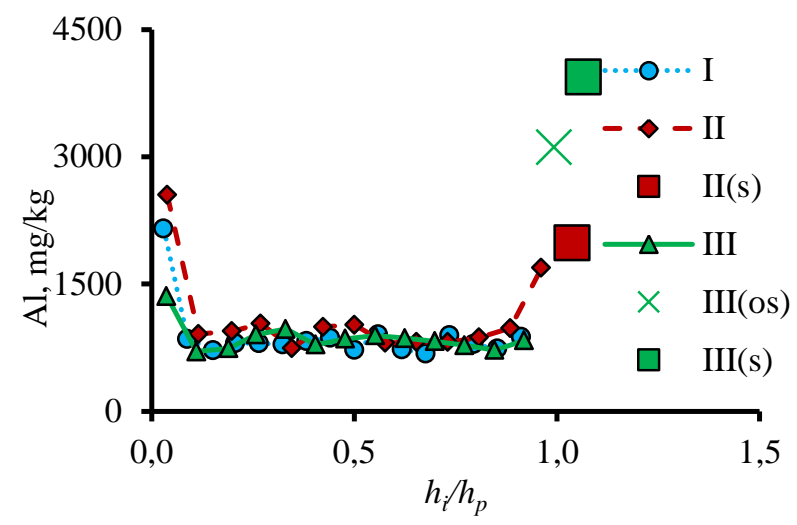

Pис. 4. Изменение значений концентрачий $\mathrm{Al}$ в кислотных вытяжках из грунтов в зависимости от относительной глубины $h_{i} / h_{p}$ в скважсинах $I$, II, III (рис. 1); $h_{i}$ - средняя глубина i-интервала опробования (через $0,25 \mathrm{M}$ ); $h_{p}$ - верхняя гранииа залегания минерального грунта; индексы «s» $u$ «оs» соответствуют минеральному грунту (суглинок) и органоминеральным отложениям

Fig. 4. Change of Al concentration depending on relative depth $h_{i} / h_{p}$ in I, II, III wells (Fig. 1); $h_{i}$ - average depth of $i$-interval of samples (through $0,25 \mathrm{~m}$ ); $h_{p}-$ top border of the basal loams; indexes «s》 and "os» correspond to the basal loams and organomineral sediments

Характер распределения физико-химических показателей, содержаний химических элементов и ассоциаций минеральных включений с глубиной в Тимирязевском болоте свидетельствует о сходстве с выявленными на Васюганском болоте закономерностями $[28,29]$. При этом нельзя не отметить меньшие значения $\mathrm{pH}$ водных вытяжек из минерального грунта в долинном переходном Тимирязевском болоте (табл. 1) по сравнению с изученным олиготрофным водораздельным участком Васюганского болота [28]. Возможно, это связано с гидрологическими условиями конкретного года. Но основным фактором представляются более благоприятные гидрогеомиграционные условия в долине р. Томи, а также более значительный приток твердого вещества (в виде взвеси) с суходолов. В результате даже на небольшой площади Тимирязевского болота $\left(0,08 \mathrm{kм}^{2}\right)$ происходит дифференциация минеральных включений в торфяной залежи по мере удаления от границы болота.

Тем не менее даже в такой обстановке происходит выведение из раствора малорастворимых соединений кальция в нижних слоях торфяной залежи (рис. 3) и формирование в инертном горизонте торфяной залежи (за исключением придонного слоя) минеральных форм алюминия. При этом нельзя исключать и образование гиббсита, что обычно наблюдается для тропических областей [32-34]. В целом именно с глинистыми минералами и другими минеральными формами алюминия связывается сорбция и, как следствие, 
повышение концентраций многих химических элементов в кислотных вытяжках, о чем свидетельствуют, например, статистически значимые связи между концентрациями $\mathrm{Al}$ и редкоземельными элементами (рис. 5).

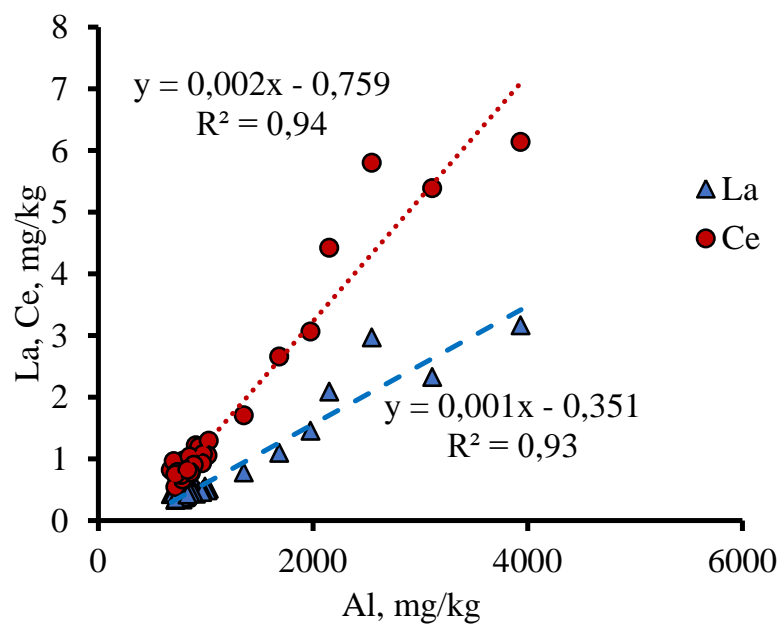

Pис. 5. Зависимость между содержаниями редкоземельных элементов (РЗЭ) и Al в кислотных вытяжках из торфов, органоминеральных отложений и минеральных грунтов

Fig. 5. Dependence between contents of rare earth elements (REE) and $A l$ in acid extracts from peats, organominerals sediments and basal loams

Кроме того, на формирование минеральных включений влияет и исходный вещественный состав подстилающих грунтов, как это было выявлено на Васюганском болоте [29], и (в какой-то степени) пылевых выпадений, на что указывают статистически значимые коэффициенты корреляции более 0,70 между содержаниями пироксенов и $\mathrm{Na}, \mathrm{V}, \mathrm{Mn}, \mathrm{Co}, \mathrm{Ni}, \mathrm{Cu}, \mathrm{Ge}$, $\mathrm{Cd}, \mathrm{Br}, \mathrm{Sr}, \mathrm{Mo}, \mathrm{Ba}, \mathrm{Cd}, \mathrm{Ba}, \mathrm{Lu}$.

\section{Заключение}

Для переходного Тимирязевского болота в долине реки Томь у г. Томска выявлено близкое к С-образному изменение по глубине зольности, $\mathrm{Al}, \mathrm{Ti}, \mathrm{Cr}$ и ряда других элементов с максимумами в верхней и нижней частях торфяной залежи пропорционально источни-

\section{СПИСОК ЛИТЕРАТУРЫ}

1. Peatlands and the carbon cycle: from local processes to global implications - a synthesis / J. Limpens, F. Berendse, C. Blodau, J.G. Canadell, C. Freeman, J. Holden, N. Roulet, H. Rydin, G. Schaepman-Strub // Biogeosciences. - 2008. - V. 5. P. $1475-1491$.

2. Shotyk W. Review of the inorganic geochemistry of peats and peatland waters // Earth-Science Reviews. - 1988. - V. 25. № 2. - P. 95-176.

3. Steinmann P., Shotyk W. Geochemistry, mineralogy, and geochemical mass balance on major elements in two peat bog profiles (Jura Mountains, Switzerland) // Chemical Geology. 1997. - V. 138. - № 1-2. - P. 25-53.

4. Methanotrophic symbionts provide carbon for photosynthesis in peat bogs / A.A. Raghoebarsing, A.J.P. Smolders, M.C. Schmid, W.I.C. Rijpstra, M. Wolters-Arts, J. Derksen, M.S.M. Jetten, S. Schouten, J.S. Sinninghe Damsté, L.P.M. Lamers // Nature. 2005. - V. 436. - № 7054. - P. 1153-1156. кам минерального вещества (в пределах очеса и самой верхней части залежи - атмосферный аэрозоль, в нижней - подстилающие грунты). Аналогичное распределение ранее было выявлено на олиготрофном водосборном участке Васюганского болота примерно в 145 км на северо-запад. Подобное распределение связано с функционированием болотной микрофлоры и геохимических барьеров на границах: 1) деятельного и инертного горизонтов торфяной залежи; 2) торфяной залежи и подстилающих минеральных грунтов $[9,35]$. Это позволяет предположить наличие общего механизма формирования вещественного состава торфов и трансформации минерального вещества в болотах с учетом фильтрационных свойств среды одного из важных факторов образования и функционирования геохимического барьера в болотной среде.

Основные черты указанного выше механизма заключаются в биохимической трансформации минеральных веществ, поступающих из атмосферы («сухое» и «мокрое» осаждение), с поверхностным и подземным стоком с суходолов, в результате чего в деятельном горизонте вещество находится в растворенном, коллоидном и взвешенном состоянии, а в инертном горизонте с большей вероятностью формируются минеральные фазы. На поверхности последних происходит соосаждение ряда микроэлементов и формирование аутигенных минералов, в том числе фосфатов РЗЭ. Скорость и направленность этих процессов зависит от геоморфологических и гидрологических условий, определяющих возникновение и функционирование геохимических барьеров. При этом влияние антропогенных факторов, безусловно, возможно. Но оно, видимо, заключается не только в непосредственном поступлении на поверхность болота загрязняющих веществ, но и в увеличении общей запыленности. В случае Тимирязевского болота нельзя не упомянуть и влияние Томского подземного водозабора, которое проявляется в основном косвенно, в увеличении амплитуды колебания уровней болотных вод, смещении и определенном «размытии» границы деятельного и инертного горизонтов торфяной залежи.

Работа выполнена при финансовой поддержке грантов РФФИ № 18-55-80015, 18-05-00302.

5. ГОСТ 21123-85. Торф. Термины и определения. Дата введения 01.07.1986 г. - М.: Изд-во стандартов, 1985. - 85 с.

6. Cohen A.D., Spackman W., Raymond R. Interpreting the characteristics of coal seams from chemical, physical and petrographic studies of peat deposits // Geological Society, London, Special Publications. - 1987. - V. 32. - № 1. - P. 107-125.

7. Modes of occurrence of rare earth elements in peat from Western Siberia / S.I. Arbuzov, S.G. Maslov, R.B. Finkelman, A.M. Mezhibor, S.S. Ilenok, M.G. Blokhin, E.V. Peregudina // Journal of Geochemical Exploration. - 2017. - V. 10. - P. 1-22. DOI: 10.1016/j.gexplo.2017.10.012.

8. Bernstein L.R. Germanium geochemistry and mineralogy // Geochimica et Cosmochimica Acta. - 1985. - V. 49. - № 11. P. 2409-2422.

9. Лиштван И.И., Базин Е.Т., Косов В.И. Физические процессы в торфяных залежах. - Минск: Наука и техника, 1989. - 287 с

10. Dai S., Graham I.T., Ward C.R. A review of anomalous rare earth elements and yttrium in coal // International Journal of Coal Geology. - 2016. - V. 159. - P. 82-95. 
11. Hedges J.I., Ertel J.R., Leopold E.B. Lignin geochemistry of a Late Quaternary sediment core from Lake Washington // Geochimica et Cosmochimica Acta. - 1982. - V. 46. - № 10. P. $1869-1877$.

12. Ogala J., Siavalas G., Christanis K. Coal petrography, mineralogy and geochemistry of lignite samples from the Ogwashi-Asaba Formation, Nigeria // Journal of African Earth Sciences. - 2012. V. 66-67. - P. 35-45.

13. Staub J.R., Cohen A.D. The Snuggedy swamp of South Carolina: a back-barrier estuarine coal-forming environment // Journal of Sedimentary Research. - 1979. - V. 49. - № 1. - P. 133-143.

14. Yudovich Y.E., Ketris M.P. Arsenic in coal: a review // International Journal of Coal Geology. - 2005. - V. 61. - № 3-4. P. 141-196.

15. Abiogenic and biogenic forms of migration compounds in swamps of different genesis / L.I. Inisheva, E.V. Porokhina, A.V. Golovchenko, L.W. Szajdak // Processes and phenomena on the boundary between biogenic and abiogenic nature: VI International Symposium. - SaintPetersburg: Saint-Petersburg State University, 2020. - P. 277-295. DOI: 10.1007/978-3-030-21614-6_16.

16. Болотные системы Западной Сибири и их природоохранное значение / О.Л. Лисс, Л.И. Абрамова, Н.А. Аветов, Н.А. Березина, Л.И. Инишева, Т.В. Курнишкова, З.А. Слука, Т.Ю. Толпышева, Н.К. Шведчикова / под ред. В.Б. Куваева. - Тула: Гриф и $\mathrm{K}^{\circ}, 2001 .-584 \mathrm{c}$.

17. Eurasian mires of the Southern Taiga Belt: modern features an response to Holocene palaeoclimate / T. Minayeva, W. Bleuten, A. Sirin, E.D. Lapshina // Wetlands and Natural Resource Management. Ecological Studies. V. 190 / Eds. J.T.A. Verhoeven, B. Beltman, R. Bobbink, D.F. Whigham. - Berlin; Heidelberg: Springer-Verlag, 2006. - P. 315-341

18. Картографирование таежных болот Западной Сибири на основе дистанционной информации / И.Е. Терентьева, И.В. Филиппов, А.Ф. Сабрекова, М.В. Глаголева, Ю.А. Курбатова, Ш Максютов // Известия РАН. Серия географическая. - 2020. T. 84. - № 6. - C. 920-930. DOI: $10.31857 / S 2587556620060102$.

19. Савичев О.Г., Шмаков А.В. Вертикальная зональность и внутригодовые изменения химического состава вод Тимирязевского болота (Томск, Западная Сибирь) // Известия Томского политехнического университета. - 2012. - Т. 320. - № 1. C. $156-156$.

20. Шмаков А.В. Гидрогеохимический режим заболоченных территорий в подтаежной зоне Западной Сибири (на примере Тимирязевского болота у г. Томска): автореф. дис. ... канд. геол.-минерал. наук. - Томск, 2016. - 21 с.

21. Колоколова О.В. Геохимия подземных вод района Томского водозабора: автореф. дис. ... канд. геол.-минерал. наук. Томск, 2003. $-21 \mathrm{c}$.

22. Межибор А.М. Экогеохимия элементов-примесей в верховых торфах Томской области: автореф. ... канд. геол.-минерал. наук. - Томск, 2009. -22 с
23. Динамика гидроморфных экосистем в зоне действия Томского водозабора / Н.В. Климова, Н.А. Чернова, Е.Н. Пац, А.Г. Дюкарев // Природопользование и охрана природы: Охрана памятников природы, биологического и ландшафтного разнообразия Томского Приобья и других регионов России: Материалы IX Всероссийской с международным участием научнопрактической конференции. - Томск: ИМКЭС СО РАН, 2020. - C. 176-180. DOI: 10.17223/978-5-94621-954-9-2020-42.

24. Состояние геологической среды (недр) на территории Сибирского федерального округа в 2018 г. Информационный бюллетень / под ред. В.А. Льготина. - Томск: Филиал «Сибирский региональный центр ГМСН», ФГБУ «Гидроспецгеология», 2019. - Вып. 15. - 218 с.

25. Пьявченко Н.И. Типы болотных лесов Томского стационара // Особенности болотообразования в некоторых лесных и предгорных районах Сибири и Дальнего Востока / под ред. Н.И. Пьявченко. - М.: Наука, 1965. - С. 97-113.

26. ГОСТ 17644-83. Торф. Методы отбора проб из залежи и обработки их для лабораторных испытаний. - М.: Изд-во стандартов, 1983. $-12 \mathrm{c}$.

27. Manual on Stream Gauging. V. I. Fieldwork. WMO. No. 1044. Geneva, Switzerland: World Meteorological Organization, 2010. $252 \mathrm{p}$.

28. Geochemical barriers in oligotrophic peat bog (Western Siberia) / O. Savichev, E. Soldatova, M. Rudmin, A. Mazurov // Applied Geochemistry. - 2020. - V. 113. - 104519. DOI: 10.1016/j.apgeochem.2019.104519.

29. Geochemical and mineralogical features of the substrates of the Vasyugan Mire, Western Siberia, Russia / M. Rudmin, M.J. Wilson, L. Wilson, O. Savichev, T. Yakich, M. Shaldybin, A. Ruban, R. Tabakaev, K. Ibraeva, A. Mazurov // Catena. 2020. - V. 194. - 104781. DOI: 10.1016/j.catena.2020.104781.

30. ГОСТ 26801-86. Торф. Метод определения зольности в залежи. - М.: Изд-во стандартов, 1986. - 5 с.

31. СП 33-101-2003. Свод правил по проектированию и строительству. Определение основных расчетных гидрологических характеристик. - М.: Госстрой России, 2004. - 72 c.

32. Drever J.I. The geochemistry of natural waters. - Englewood Cliffs: Prentice-Hall, Inc., 1982. -440 p.

33. Shvartsev S.L. Geochemistry of fresh groundwater in the main landscape zones of the Earth // Geochemistry International. 2008. - V. 46. - № 13. - P. 1285-1398.

34. Clay mineral solubility from aqueous equilibrium: Assessment of the measured thermodynamic properties / S. Gaboreau, H. Gailhanou, Ph. Blanc, Ph. Vieillard, B. Made // Applied Geochemistry. - 2020. - V. 113. - 104465. DOI: 10.1016/j.apgeochem.2019.104465.

35. Бахнов В.К. Почвообразование. Взгляд в прошлое и настоящее (биосферные аспекты). - Новосибирск: Изд-во СО РАН, 2002. $-117 \mathrm{c}$.

Поступила 24.02.2021 г.

\section{Информация об авторах}

Савичев О.Г., доктор географических наук, профессор отделения геологии Инженерной школы природных ресурсов Национального исследовательского Томского политехнического университета.

Pудмин М.A., кандидат геолого-минералогических наук, доцент Инженерной школы природных ресурсов Национального исследовательского Томского политехнического университета.

Мазуров А.К., доктор геолого-минералогических наук, профессор Инженерной школы природных ресурсов Национального исследовательского Томского политехнического университета.

Федченко A.C., магистрант Инженерной школы природных ресурсов Национального исследовательского Томского политехнического университета.

$\boldsymbol{P} \boldsymbol{y} \boldsymbol{a} \boldsymbol{\mu} \boldsymbol{A} . \boldsymbol{C}$., кандидат геолого-минералогических наук, доцент Инженерной школы природных ресурсов Национального исследовательского Томского политехнического университета.

Даулетова А.Б., аспирант отделения геологии инженерной школы природных ресурсов Национального исследовательского Томского политехнического университета. 
UDC 550.46

\title{
MATERIAL COMPOSITION OF PEATS OF THE TIMIRYAZEVO MIRE (TOMSK, WESTERN SIBERIA)
}

\author{
Oleg G. Savichev ${ }^{1}$, \\ OSavichev@mail.ru \\ Maxim A. Rudmin', \\ RudminMA@tpu.ru \\ Aleksey K. Mazurov'1, \\ AKM@tpu.ru
}

\section{Artyom S. Fedchenko1, Artem_Fedchenko97@mail.ru}

Alexey S. Ruban ${ }^{1}$, Ruban@tpu.ru

\author{
Aigerim B. Dauletova ${ }^{1}$, \\ Ikerimdb@gmail.com \\ 1 National Research Tomsk Polytechnic University, \\ 30, Lenin avenue, Tomsk, 634050, Russia.
}

Relevance. Mires are simultaneously the indicator of the environment condition, including the river and ground waters connected to mires. It is especial in the area of accommodation of a large drinking water supply system, for example, the Tomsk system of drinking water supply from groundwaters.

The aim of the research is to reveal the changes of the chemical composition (acid peat extracts) and mineral inclusions as indicators of mire formation conditions according to nature and anthropogenous influence in the peat deposit of the Timiryazevo mire (the western corner of Tomsk city, Western Siberia).

Methods: methods of definition of chemical and mineral composition of peat and soils, statistical methods.

Results and conclusions. An uneven change of ash content, $\mathrm{Al}, \mathrm{Ti}, \mathrm{Cr}$ and other elements was revealed with a maximum in the upper and lower layers of the peat deposit in proportion to mineral sources (atmospheric dust and underlying clays, respectively) for mesotrophic Timiryazevo mire in the Tom river valley near the Tomsk city. An assumption is made about the presence of a general mechanism for peat formation and the transformation of mineral inclusions in mires based on the environment filtration properties taking into account the previously obtained data for the Vasyugan mire. The main features are the biochemical transformation of mineral substances coming from the atmosphere, or surface and ground flow from drylands. As a result, the substance is in a dissolved, colloidal and suspended form in the active horizon. Mineral phases are formed in the inert horizon. Trace elements co-precipitate on the surface of these particles (also particles of hydroxides) and authigenic minerals including phosphates of rare earth elements are formed. The velocity and direction of these processes depend on the geomorphological and hydrological conditions that determine the emergence and functioning of geochemical barriers.

\section{Key words:}

Chemical and mineral composition, peat deposit, geochemistry, Timiryazevo mire, Tomsk city, Western Siberia.

The research was financially supported by the RFBR grants no. 18-55-80015 and 18-05-00302.

\section{REFERENCES}

1. Limpens J., Berendse F., Blodau C., Canadell J.G., Freeman C., Holden J., Roulet N., Rydin H., Schaepman-Strub G. Peatlands and the carbon cycle: from local processes to global implications a synthesis. Biogeosciences, 2008, vol. 5, pp. 1475-1491.

2. Shotyk W. Review of the inorganic geochemistry of peats and peatland waters. Earth-Science Reviews, 1988, vol. 25, pp. 95-176.

3. Steinmann P., Shotyk W. Geochemistry, mineralogy, and geochemical mass balance on major elements in two peat bog profiles (Jura Mountains, Switzerland). Chemical Geology, 1997, vol. 138, pp. 25-53.

4. Raghoebarsing A.A., Smolders A.J.P., Schmid M.C., Rijpstra W.I.C., Wolters-Arts M., Derksen J., Jetten M.S.M., Schouten S., Sinninghe Damsté J.S., Lamers L.P.M. Methanotrophic symbionts provide carbon for photosynthesis in peat bogs. Nature, 2005, vol. 436, pp. 1153-1156.

5. GOST 21123-85. Torf. Terminy i opredeleniya [SS 21123-85. Peat. Terms and definitions]. Moscow, Izdatelstvo standartov, 1985. $85 \mathrm{p}$.
6. Cohen A.D., Spackman W., Raymond R. Interpreting the characteristics of coal seams from chemical, physical and petrographic studies of peat deposits. Geological Society, Special Publications. London, 1987, vol. 32, pp. 107-125.

7. Arbuzov S.I., Maslov S.G., Finkelman R.B., Mezhibor A.M., Ilenok S.S., Blokhin M.G., Peregudina E.V. Modes of occurrence of rare earth elements in peat from Western Siberia. Journal of Geochemical Exploration, 2017, no. 10, pp. 1-22. DOI: 10.1016/j.gexplo.2017.10.012.

8. Bernstein L.R. Germanium geochemistry and mineralogy. Geochimica et Cosmochimica Acta, 1985, vol. 49, pp. 2409-2422.

9. Lishtvan I.I., Bazin E.T., Kosov V.I. Fizicheskie protsessy v torfyanykh zalezhakh [Physical processes in peat deposits]. Minsk, Nauka i tekhnika, 1989. $287 \mathrm{p}$.

10. Dai S., Graham I.T., Ward C.R. A review of anomalous rare earth elements and yttrium in coal. International Journal of Coal Geology, 2016, vol. 159, pp. 82-95.

11. Hedges J.I., Ertel J.R., Leopold E.B. Lignin geochemistry of a Late Quaternary sediment core from Lake Washington. Geochimica et Cosmochimica Acta, 1982, vol. 46, pp. 1869-1877. 
12. Ogala J., Siavalas G., Christanis K. Coal petrography, mineralogy and geochemistry of lignite samples from the Ogwashi-Asaba Formation, Nigeria. Journal of African Earth Sciences, 2012, vol. 66-67, pp. 35-45.

13. Staub J.R., Cohen A.D. The Snuggedy swamp of South Carolina: a back-barrier estuarine coal-forming environment. Journal of Sedimentary Research, 1979, vol. 49, pp. 133-143.

14. Yudovich Y.E., Ketris M.P. Arsenic in coal: a review. International Journal of Coal Geology, 2005, vol. 61, pp. 141-196.

15. Inisheva L.I., Porokhina E.V., Golovchenko A.V., Szajdak L.W Abiogenic and biogenic forms of migration compounds in swamps of different genesis. Processes and phenomena on the boundary between biogenic and abiogenic nature. VI International Symposium. Saint-Petersburg, Saint-Petersburg State University, 2020. pp. 277-295. DOI: 10.1007/978-3-030-21614-6_16.

16. Liss O.L., Abramova L.I., Avetov N.A. Bolotnye sistemy Zapadnoy Sibiri i ikh prirodookhrannoe znachenie [Bog of Western Siberia and their conservation value]. Tula, Grif i K ${ }^{\circ}$ Publ., 2001. $584 \mathrm{p}$.

17. Minayeva T., Bleuten W., Sirin A., Lapshina E.D. Eurasian mires of the Southern Taiga Belt: modern features and response to Holocene palaeoclimate. Wetlands and Natural Resource Management Ecological Studies. Vol. 190. Eds. J.T.A. Verhoeven, B. Beltman, R. Bobbink, D.F. Whigham. Berlin Heidelberg, Springer-Verlag, 2006. pp. 315-341.

18. Terentyeva I.E., Filippov I.V., Sabrekova A.F., Glagoleva M.V., Kurbatova Yu.A., Maksyutov Sh. Mapping of taiga bogs in Western Siberia based on remote sensing information. Izvestiya RAN. Seriya geograficheskaya, 2020, vol. 84, no. 6, pp. 920-930. In Rus. DOI: $10.31857 / \mathrm{S} 2587556620060102$

19. Savichev O.G., Shmakov A.V. Vertical zoning and intra-annual changes in the chemical composition of the waters of the Timiryazev bog (Tomsk, Western Siberia). Bulletin of the Tomsk Polytechnic University, 2012, vol. 320, no. 1, pp. 156-156. In Rus.

20. Shmakov A.V. Gidrogeokhimicheskiy rezhim zabolochennykh territoriy v podtayezhnoy zone Zapadnoy Sibiri (na primere Timiryazevskogo bolota u g. Tomska). Avtoreferat Diss. Kand. nauk [Hydrogeochemical regime of wetlands in the subtaiga zone of Western Siberia (on the example of the Timiryazevsky bog near the city of Tomsk). Cand. Diss. Abstract]. Tomsk, 2016.21 p.

21. Kolokolova O.V. Geokhimiya podzemnykh vod rayona Tomskogo vodozabora. Avtoreferat Diss. Kand. nauk [Geochemistry of groundwater in the Tomsk water intake area. Cand. Diss. Abstract] Tomsk, 2003. $21 \mathrm{p}$

22. Mezhibor A.M. Ekogeokhimiya elementov-primesey v verkhovykh torfakh Tomskoy oblasi. Avtoreferat Diss. Kand. Nauk [Ecogeochemistry of accessories elements in riding peats of the Tomsk area. Cand. Diss. Abstract]. Tomsk, 2009. 22 p.

23. Klimova N.V., Chernova N.A., Pats E.N., Dyukarev A.G. Dinamika gidromorfnykh ekosistem $\mathrm{v}$ zone deystviya Tomskogo vodozabora [Dynamics of hydromorphic ecosystems in the area of the Tomsk water intake]. Prirodopolzovaniye i okhrana prirody: Okhrana pamyatnikov prirody, biologicheskogo i landshaftnogo raznoobraziya Tomskogo Priobya i drugikh regionov Rossii [Dynamics of hydromorphic ecosystems in the area of the Tomsk wa- ter intake]. Tomsk, Institute of monitoring SB RAS Publ., 2020. pp. 176-180. DOI: 10.17223/978-5-94621-954-9-2020-42.

24. Sostoyanie geologicheskoy sredy (nedr) na territorii Sibirskogo federalnogo okruga v 2018 g. [Condition of the geological environment (subsoil) in the territory of Siberian Federal District in 2018.]. Informatsionny byulleten [Information bulletin]. Ed. by V.A. Lgotin. Tomsk, Siberian Federal centre «GMSN» branch, Gidrospetsgeologiya Publ., 2019. Iss. 15, 218 p.

25. Pyavchenko N.I. Tipy bolotnykh lesov Tomskogo statsionara [Types of bog forests of the Tomsk station]. Osobennosti bolotoobrazovaniya $v$ nekotorykh lesnykh i predgornykh rayonakh Sibiri i Dalnego Vostoka [Peculiarities of bog formation in some forest and foothill regions of Siberia and the Far East]. Moscow, Nauka Publ., 1965. pp. 97-113.

26. GOST 17644-83. Torf. Metody otbora pro biz zalezhi i obrabotki ikh dlya laboratornykh ispytany [SS 17644-83Peat. Methods of sampling from deposit and preparation of samples for laboratory tests]. Moscow, Izdatelstvo standartov Publ., 1983. 12 p.

27. Manual on Stream Gauging. Vol. I. Fieldwork. WMO-No. 1044. Geneva, Switzerland, World Meteorological Organization, 2010. $252 \mathrm{p}$

28. Savichev O., Soldatova E., Rudmin M., Mazurov A. Geochemical barriers in oligotrophic peat bog (Western Siberia). Applied Geochemistry, 2020, vol. 113, 104519. DOI: 10.1016/j.apgeochem. 2019.104519.

29. Rudmin M., Wilson M.J., Wilson L., Savichev O., Yakich T., Shaldybin M., Ruban A., Tabakaev R., Ibraeva K., Mazurov A. Geochemical and mineralogical features of the substrates of the Vasyugan Mire, Western Siberia, Russia. Catena, 2020, vol. 194, 104781. DOI: 10.1016/j.catena.2020.104781.

30. GOST 26801-86. Torf. Metod opredeleniya zolnosti v zalezhi [SS 26801-86 Peat. Method for determination of ash content in deposit]. Moscow, Izdatelstvo standartov Publ., 1986. 5 p.

31. SP 33-101-2003. Svod pravil po proyektirovaniyu i stroitelstvu. Opredelenie osnovnykh raschetnykh gidrologicheskikh kharakteristik [Code of rules for design and construction. Determination of the main calculated hydrological characteristics]. Moscow, Gosstroy of Russia Publ., 2004. 72 p.

32. Drever J.I. The geochemistry of natural waters. Englewood Cliffs, Prentice-Hall, Inc., 1982. 440 p.

33. Shvartsev S.L. Geochemistry of fresh groundwater in the main landscape zones of the Earth. Geochemistry International, 2008, vol. 46, no. 13, pp. 1285-1398.

34. Gaboreau S., Gailhanou H., Blanc Ph., Vieillard Ph., Made B. Clay mineral solubility from aqueous equilibrium: Assessment of the measured thermodynamic properties. Applied Geochemistry, 2020, vol. 113, 104465. DOI: 10.1016/j.apgeochem.2019.104465.

35. Bakhnov V.K. Pochvoobrazovanie. Vzglyad v proshloe i nastoyashchee (biosfernye aspekty) [Soil formation. A look into the past and the present (biospheric aspects)]. Novosibirsk, SB RAS Publ. house, 2002. $117 \mathrm{p}$.

Received: 24 February 2021.

\section{Information about the authors}

Oleg G. Savichev, Dr. Sc., professor, National Research Tomsk Polytechnic University.

Maxim A. Rudmin, Cand. Sc., associate professor, National Research Tomsk Polytechnic University.

Aleksey K. Mazurov, Dr. Sc., professor, National Research Tomsk Polytechnic University.

Artyom S. Fedchenko, student, National Research Tomsk Polytechnic University.

Alexey S. Ruban, Cand. Sc., associate professor, National Research Tomsk Polytechnic University.

Aigerim B. Dauletova, graduate student, National Research Tomsk Polytechnic University. 